\title{
ÁREAS DE ALIMENTAÇÃO
}

Fronteiras entre a área do milho e a área da mandioca. Fatôres naturais que as determinam. Contribuição para o seu conhecimento no Estado de São Paulo.

\section{Carlos Borges Schmidt}

Entre vários fatôres, o clima condiciona a adoção de certos e determinados alimentos básicos, principalmente na zona rural. Como exemplo, pode ser apontado aquilo que aqui ocorre entre o milho e a mandioca. Enquanto a importante raiz alimentícia distingue as áreas de clima tropical com a sua preferência, já o tradicional alimento das civilizações andinas aponta como eleita pelas suas exigências aquêles espaços em que um clima ameno e suave predomina. E' a bacia amazônica e o Feru. Beira-mar e serra acima.

A primeira dessas plantas dá-se muito bem numa região de temperatura mais elevada e maior altura de precipitações, enquanto a última possui o seu clima ideal onde possam ser encontradas as propícias condições derivadas de uma temperatura menos elevada; períodos chuvosos menos prolongados e precipitações totais mais modestas. E' o binômio chuva-calor, em suas múltiplas combinações, que determina, principalmente, o ótimo climático para cada um daqueles produtos agrícolas. $\mathrm{E}$, conseqüentemente, o seu emprêgo como alimento principal das populações rurais locais, estabelecendo, com a interferência de algumas outras causas, de menor importância, verdadeiras áreas de alimentação, com limites mais ou menos precisos e delineados.

Já tivemos o ensejo de, certa vez, relativamente a São Paulo, tratar do assunto de um modo geral. "Dêsse ponto de vista, em duas amplas zonas pode ser dividido o Estado: a zona da farinha de mandioca, abrangendo a vertente marítima, e a zona da farinha de milho, que se estende por tôda a região da serra acima. Nesta última, duas zonas menores podem ser determinadas. A primeira é a de farinha de milho, pròpriamente dita, f̧ita mediante a maceração, piloamento e torração do cereal, que abrange a bacia do Paraíba, e quase tôda a região acidentada pelos contrafortes da cordilheira marítima - o primeiro planalto, como é por alguns denominada. Em certos pontos desta zona, muitos recusam-se; terminantemente, a comer o fubá. Dizem que aquilo é quirera, e que quirera é comida para cachorro... A outra é a parte restante do planalto, mais influenciada pela imigração, onde o milho é usado, na alimentação, principalmente sob a forma de fubá" ${ }^{1}$. O angu caboclo $€$ a polenta italiana. 
Interessante percorrer um pouco suas linhas de contacto, embora não muito "igorosamente definidas, em virtude dos numerosos fatôres que, forçosamente, devem aí influir, com maior ou menor intensidade. Nas vizinhanças de São Paulo, além de Santo Amaro, estão as 10calidades de Parelheiros e Colônia, região onde, faz pouco mais de um século, ocorreu a primeira colonização oficial do govêrno da Província, com imigrantes alemães. Ali, informou um descendente dos primitivos colonos, "o pessoal da roça tanto consome a farinha de mandioca como a de milho". Por isso que "os engenhos de farinha", como são chamados, tanto os de milho como os de mandioca, coexistem, e, de maneira constante, no mesmo local, casa ou rancho. A fôrça hidráulica aciona os dois maquinismos: o pilão para socar o milho fermentado e a roda de ralar as raízes da mandioca. Seria êste local um dos pontos da zona de contacto entre as duas áreas culturais de alimentação básica: a da farinha de mandioca, com sua retaguarda no litoral, e que até ali tivesse vindo ter, depois de vencer a Serra do Mar, como que invadindo o planalto; e a da farinła de milho, característica das terras altas, de clima mais ameno, que se estendem pelo interior a dentro, e que naquele local estacou, sem encorajar-se a descer para a beira-mar.

Do lado oposto da Capital paulista, para as bandas do vale do $\mathrm{Pa}$ raitinga, fato semelhante ocorreu, embora não de maneira tão marcante. Nessa região a farinha de milho é aquela considerada como básica nos hábitos alimentares do caboclo. Entretanto, as pequenas fábricas onde se produz farinha de mandioca, também para o consumo da população rural e dos centros urbanos, podem ser encontrados a miúde. Entre São Luís do Paraitinga e Lagoinha, rio acima, existem algumas delas. Assim nos kairros das Perobas, Caieira, Ribeirão das Almas, Alvarenga, Cachoeira, Turvo, Correas e, também, ao longo da estrada de rodagem Taubaté-São Luís do Paraitinga. Êstes locais encontram-se no Vale do Paraitinga ou na sua contravertente, para os lados do Paraíba, porém ainda na reģião bastante ondulada e que se situa entre êste vale e o divisor de águas Paraíba-Paraitinga. Zona acidentada e cujo clima é bem mais suave que o do referido vale. Rio Abaixo, como é chamada a região a jusarte de São Luís do Paraitinga, é zona onde inexiste fábrica de farinha de mandioca. Fato idêntico ocorre na região situada entre São Luís do Paraitinga e a Serra do Mar, rumo de Ubatuba. São áreas já de clima mais frio e, portanto, menos próprio para o cultivo da mandioca. Um exemplo die coexistência das duas fábricas na mesma propriedade pode ser apontado na área entre São Luís do Paraitinga e Lagoinha, no bairro da Água Santa. No sítio, os moradores usam da mesma farinha. Farinha de mandioca para comida de sal. Farinha de miIho para idêntico fim e ainda para tomar com café. As filhas e a mulher do sitiante é que se incumbem da preparação dos dois produtos alimentares básicus. Possuem, para isso, roda de ralar, prensa de fuso, forno 
e monjolo. Esta gente, aliás, é muito esforçada e trabalhadora. Além dessas duas fabriquetas, fazem grande cópia de utensílios de cerâmica, das mais originais e de grande procura na região. Uma cerâmica bastante típica e incomum em outros pontos do Estado.

O ciclo vegetativo da planta, ou melhor, o tempo que a planta leva para produzir, desde seu plantio até a colheita, varia muito de uma região para outra. A mandioca, por exemplo, pode produzir, no litoral paulista, até em dez meses apenas, depois de plantada. No interior do Estado, a plantação industrial da raiz, destinada às grandes fábricas de farinha, tem sua colheita iniciada desde quando a planta atinge de 14 a 16 meses de idade. Já na região montuosa, que orla o planalto, acompanhando a Serra do Mar, atrás mencionada, o amadurecimento da planta exige, em geral, até 24 meses de chão, do plantio à colheita, para dar rendimento razoável. Dois anos de trato de um cultivo qualquer encarece sobremodo o produto, e desanima mesmo.

Pode-se, entretanto, admitir que mesmo numa região tal como a última, acima mencionada, existam certas áreas limitadas, onde a planta da mandioca caminha mais ràpidamente, produzindo de maneira aceitável. Aqui, vale lembrar o que aconteceu com as lavouras de algodão na bacia do Paraíba, em território paulista, por volta do final da décadia dos trinta e comêço dos quarenta. Foi tentado, pode-se dizer mesmo, em grande escala, o cultivo do algodoeiro naquela zona. Vários anos seguidos, todos os que nela se meteram tiveram prejuízo. O algodoeiro, de maneira alguma, ia para a frente. O frio aparecia durante o verão, quando menos se esperava, e aquêles dias de queda termométrica durante o desenvolvimento da planta, prejudicavam bastante a lavoura. E o inverno, êsse então, entrava cêdo, quando os capuchos, ainda fechados pela lerdeza da vegetação, viam interrompido o seu ciclo vegetativo, murchavam e morriam. Mas existia um oásis, no meio disso tudo. Como uma área eleita pelo capricho da natureza: Paraibuna. Ali as lavouras se dosenvolviam de maneira relativamente normal e apresentavam produção bastante razoável. E, entretanto, situada na mesma área serrana do Estado, que os demais municípios da bacia do Paraíba, nada que justificasse, pelo menos aparentemente, uma diferença tão grande de resultado, podia ser percebido nas suas condições climáticas. Umas nuances imferceptiveis no clima, e resultados tão marcantes, afinal. Assim com o algodoeiro, assim também poderia ser com a mandioca.

Agora, em contrapartida, o milho no litoral quente e úmido. Ali o cultivo econômico do milho é, pràticamente, inviável. O excesso de precipitações pluviométricas e os exagerados e prolongados calores do verão, impedem que o cereal complete, regularmente, o seu ciclo vegetativo. Que complete a fase final de sua vida, amadurecendo e secando normalmente. O clima local the é adverso. De um modo normal, a espiga de milho deveria, depois de granada e amadurecida completamen- 
te, dobrar o engaço e virar para baixo, de forma que a sua palha passasse a desempenhar um verdadeiro papel de "telhado", impedindo que chuvas everıtuais, depois de passado o rigor das águas, penetrassem no interior das espigas e ali provocassem a deterioração dos grãos. Mas no litoral isto não ocorre, ou pelo menos não se verifica no total de sua área, o suficiente para tornar anti-econômica a lavoura do milho na baixada maritima paulista. Acontece que o calor e a umidade prolongada, bem além do que a planta necessita, impedem que a sua vegetação cesse de vez, mantendo-se o pé com fôlhas sêcas e verdes, e as espigas erectas, recebendo novas precipitações que nelas penetram, atingindo e promovendo a deterioração dos grãos.

Eis a razão pela qual o cultivo do milho no litoral paulista é raro e restrito a áreas muito pequenas, uma vez que para aproveitamento das espigas é exigido um trabalho complementar, qual seja o de virá-las à mão, para baixo, ou colhê-las e antes de empaiolá-las promover a sua sêca ao sol, no terreiro, ou, amarradas de duas em duas, deixá-las ao tempo em um varal, para uma secagem mais perfeita, e total. Contràriamente ao que ocorre no planalto bandeirante, onde as condições climáticas, como de propósito, se ajustam às exigências do cereal americano. A maturação do milho coincide com o final da estação chuvosa. Maduro, o pé de milho seca logo. Com êle o engaço; êste sêco ou murcho, a espiga vira de ponta para baixo, e qualquer chuva, fora já de tempo, é inofensiva. A espiga seca no pé e ali pode ficar, até que num vagar o lavradcr, sem preocupações, promova a sua colheita.

De um modo geral é isso o que acontece. E essa é a razão pela qual o cultivo do milho inexiste, em bases de economia agrícola, no litoral paulista. Motivo, afinal, pelo qual o seu uso na alimentação humana, na zona rural, pràticamente não ocorre. Êle está, destarte, ausente na dieta caiçara. $\mathrm{E}$ dos animais domésticos, como na engorda de suínos, aparecendo, produzido em meia dúzia de pés, ou importado de serra-acima, aos pequenos punhados, mais para manter a galinhada ao redor das habitações, que para alimentá-la.

Há algum tempo atrás, por motivos óbvios, tivemos oportunidade de fazer referência ao fato, e pela importância que o mesmo poderia apresentar em certa ordem de estudos, procuramos aqui objetivá-lo, recorrendo a notas apanhadas, desde anos passados, de permeio com outras relativas a assuntos diversos. Dada a variabilidade dos informes assim previstos, apelamos para os conhecimentos de pessoas bastante entendidas em agricultura, e chegamos à conclusão de que elas, também, não estavam perfeitamente senhoras da questão, em virtude, é claro, da falta de significado econômico que tal fenômeno apresenta no cultivo do milho no litoral, por isso mesmo exploração agrícola sem nenhum relêvo na área costeira do Estado de São Paulo. As notas a seguir são di- 
vulgadas com a finalidade de servirem de sugestão aos que se interessarem por pesquisas ulteriores.

Com base em informações locais registramos em 1930, relativamente a Ubatuba, que o milho "deve ser plantado nos meses de julho, agôsto e setembro. Se plantado muito tarde, produz uma porção de espigas que rião passarão de restolhos". E mais adiante: "A espiga, mesmo depois de madura, não deita. Precisa ser quebrado e acabado de secar ao sol. Do contrário, os grãos germinarão na espiga" ${ }^{2}$. O milho de ciclo longo, no planalto, deve ser plantado na segunda quinzena de outubro; o outrc, o de ciclo curto, pode ser semeado algum tempo depois. Êles irão, assim, granar em fevereiro, que é o mês, segundo as normas climáticas, em que menor perigo haverá de faltaram chuvas, nesse momento críticc da vida do cereal. Ali mesmo em Ubatuba, um lavrador plantou meio litro de milho "catetão", $\in \mathrm{m}$ julho, e colheu oitenta em fins de dezembro. Produção excelente: 1 x 160. Mas teve que colher e secar no varal, à moda da terra. Em 1942 ouvimos dizer em São Sebastião: "A planta preferida é a de junho, do milho "branco". Plantado mais tarde, espiga muito e dá milho miúdo. O milho "amarelo" pode ser plantado até em novembro. O milho vira bem quando seca (Praia das Pitangueiras)". Este "vira bem quando seca" poderia parecer contraditório. Como não estávamos especialmente interessados no assunto, por aquela época - três lustros já passados - bem que poderia ter querido dizer o caiçara que não havia dificuldade em virá-lo, quando maduro, à mão: quando seca, "vira bem". Uma mera suposição, claro. Alguns anos mais tarde (1946) registramos na Ilha de São Sebastião: "Na Ilha o milho não vira a espiga".

Andando para o sul, tomamos as seguintes notas em Peruíbe (1943): "O milho nãc vira, nem na praia e nem no sertão. Colhem o milho, amarram os pares de espigas que a seguir são dependuradas num varal, para secar". Mais para lá, na Ilha do Cardoso, anotamos, relativamente aos produtos ali cultivados (1946): "Arroz, feijão, cana, mandioca, batatadoce, aipi, taiá (taioba); milho algum, não vira e nasce raquítico". $\mathrm{Na}$ planície inteina da bacia do Rio da Ribeira de Iguape (Registro, em 1941): "Ao contrário do que acontece em outros pontos da vertente marítima próxima ao Oceano - êle completa, normalmente, a sêca da espiga no próprio pé, virando-a para baixo e dêsse modo livrando-a da penetração das chuvas tardias" ". Uma última anotação, esta fora de São Paulo, no vizinho Estado do Rio, em Parati (1945): "Fazenda Santa Maria, no outro lado da enseada. Engenho antigo. Dá milho que vira no pé. Costumam até deixá-lo na roça para guardar a semente até a outra planta. As chuvas vão de outubro a março".

Recentemente, em busca de novos esclarecimentos, ouvimos uma daquelas atrás referidas. Pessoa bastante informada em relação à agricultura litorânea, declarou que "o milho não vira a espiga, mesmo, e em 
todo lugar é assim. Tanto no litoral como no planalto. Quando chega no ponto, a gente vira a espiga no próprio pé, ou então colhe o milho e põe as espigas, amarradas de duas em duas, num varal, ou no terreiro para secarem. até que fiquem em condições de serem empaioladas". Explicamos que tal não ocorre no planalto paulista, eis que a espiga vira por si sć e ali fica, sem perigo algum de deterioração, exclusive caruncho, até que sobre tempo ao lavrador para realizar a colheita.

Outras daquelas pessoas, consultadas, nada puderam adiantar em relação ao assunto, ainda não suficientemente observado por elas. Uma dessas pessoas, de momento, disse atribuir o fato à variedade do milho plantado, o que parece não proceder de forma alguma. Um dos me1hores conhecedores do assunto, declarou não possuir suficientes informações sôbre se o milho, em geral, vira ou não vira por si na planície costeira. Esclareceu, todavia, que no planalto uma certa porcentagem do milho não vira a espiga para baixo, fato considerado na seleção de sementes como fator negativo. Admitia, entretanto, que êsse fato podia ser atribuído às condições do engaço. Se o engaço é pequeno e de internódios curtos, a tendência é para não virar. Inversamente, se o engaço é longo e os internódios compridos, não há como não virar. Tal fato, no planalto, passaria desapercebido dos agricultores, eis que a espiga não correria o risco de deterioração. Sugeriu, também, a possibilidade de uma podridão (doença), que ocorre nas espigas de milho, e que no litoral, em face do clima úmido, poderia apresentar maior incidência, levando à falsa suposição de que as chuvas seriam os fatôres responsáveis diretos. A isso temos a objetar que é tão grande a generalização do fenômeno que, de forma alguma, aquelas razões poderiam ser aceitas. Aliás, o nosso informante explicou que aquela era uma suposição assim sem maiores fundamentos, pois desconhecia, de experiência própria, aquêle fator limitativo, ou mesmo impeditivo, em relação ao cultivo do milho no nosso litoral - as espigas não viram naturalmente.

Isto, de qualquer forma, seria, se verdadeiro, uma resultante, afinal, ¿ŕs próprias condições climáticas da região, impedientes do cultivo do milho e determinantes da alimentação básica de sua população rural.

\section{NOTAS}

(1) Carlos Borges Schmidt, "O Meio Rural", Diretoria de Publicidade Agricola da Secretaria da Agricultura, 2a. edição, São Paulo, 1945, pág. 50 .

(2) Carlos Borges Sch.rridt, "A Cultura Prática da Bananeira Nanica no Litoral Norte Paulista", Diretoria de Publicidade Agrícola. Secretaria da Agricultura. São Paulo, 1934, pág. 70 .

(3) Carlos Borges Schmidt, "Paisagens Rurais", in Boletim de Agricultura. Dirctoria de Publicidade Agrícola. Secretaria da Agricultura Número único de 1942. São Paulo, pág. 148. 